\title{
Mesocosm experiments on nutrient and fish effects on shallow lake food webs in a Mediterranean climate
}

\author{
SUSANA ROMO, MARÍA R. MIRACLE, MARÍA-JOSÉ VILLENA, JUAN RUEDA, \\ CARMEN FERRIOL AND EDUARDO VICENTE \\ Unidad de Ecología, Facultad de Biología, Universitat de València, Campus Burjasot, Burjasot, Valencia, Spain
}

\section{SUMMARY}

1. Nutrient and fish manipulations in mesocosms were carried out on food-web interactions in a Mediterranean shallow lake in south-east Spain. Nutrients controlled biomass of phytoplankton and periphyton, while zooplankton, regulated by planktivorous fish, influenced the relative percentages of the dominant phytoplankton species.

2. Phytoplankton species diversity decreased with increasing nutrient concentration and planktivorous fish density. Cyanobacteria grew well in both turbid and clear-water states. 3. Planktivorous fish increased concentrations of soluble reactive phosphorus (SRP). Larger zooplankters (mostly Ceriodaphnia and copepods) were significantly reduced when fish were present, whereas rotifers increased, after fish removal of cyclopoid predators and other filter feeders (cladocerans, nauplii). The greatest biomass and diversity of zooplankton was found at intermediate nutrient levels, in mesocosms without fish and in the presence of macrophytes.

4. Water level decrease improved underwater light conditions and favoured macrophyte persistence. Submerged macrophytes (Chara spp.) outcompeted algae up to an experimental nutrient loading equivalent to added concentrations of $0.06 \mathrm{mg} \mathrm{L}^{-1} \mathrm{PO}_{4}-\mathrm{P}$ and $0.6 \mathrm{mg} \mathrm{L}^{-1} \mathrm{NO}_{3}-\mathrm{N}$, above which an exponential increase in periphyton biomass and algal turbidity caused characean biomass to decline.

5. Declining water levels during summer favoured plant-associated rotifer species and chroococcal cyanobacteria. High densities of chroococcal cyanobacteria were related to intermediate nutrient enrichment and the presence of small zooplankton taxa, while filamentous cyanobacteria were relatively more abundant in fishless mesocosms, in which Crustacea were more abundant, and favoured by dim underwater light.

6. Benthic macroinvertebrates increased significantly at intermediate nutrient levels but there was no relationship with planktivorous fish density.

7. The thresholds of nutrient loading and in-lake P required to avoid a turbid state and maintain submerged macrophytes were lower than those reported from temperate shallow lakes. Mediterranean shallow lakes may remain turbid with little control of zooplankton on algal biomass, as observed in tropical and subtropical lakes. Nutrient loading control and macrophyte conservation appear to be especially important in these systems to maintain high water quality.

Keywords: benthos, lake management, Mediterranean, nutrients, planktivorous fish, plankton

Correspondence: Susana Romo, Unidad de Ecología,

Facultad de Biología, Universitat de València, Campus Burjasot,

E-46100 Burjasot, Valencia, Spain.

E-mail: susana.romo@uv.es

(C) 2004 Blackwell Publishing Ltd

\section{Introduction}

Food web manipulations to switch turbid, planktondominated lakes to clear-water, macrophyte-dominated systems, have mostly been carried out on shallow 
temperate lakes (Scheffer et al., 1993; Perrow et al., 1997; Drenner \& Hambright, 1999; Mehner et al., 2002) and have contributed greatly to a general understanding of the functioning of these systems. Comparable information on tropical and subtropical lakes remains restricted, however (John, 1986; Lazzaro, 1997; Talling \& Lemoalle, 1998; Bachmann, Hoyer \& Canfield, 1999), and is virtually lacking from semi-arid and Mediterrranean areas (Galanti, Guilizzoni \& Libera, 1990; Beklioglu, Ince \& Tuzun, 2003). Climate and hydrological regimes are likely to affect lake communities differently in warmer regions (Jeppesen et al., 2003). For example, high annual temperatures influence fish growth and predation rates on zooplankton (Bachmann et al., 1996). In tropical lakes, fish may maintain a quasi-permanent size-selective predation pressure on zooplankton, which leads to reduced abundance of large-bodied herbivorous crustaceans (Lazzaro, 1997).

Compared with cooler systems, subtropical and tropical lakes tend to have very small zooplankters (Fernando, 1994), which in addition to reduced competition from large zooplankton taxa, can be physiologically better adapted to higher temperatures (Atkinson, 1994; Moore, Folt \& Stemberger, 1996). Therefore, in warmer lakes, zooplankton may have weaker control of algal biomass (Fernando, 1994; Lazzaro, 1997; Benndorf et al., 2001). Furthermore, high zooplanktivore biomass and small-bodied zooplankters may enhance nutrient cycling and algal growth (Fernando, 1994; Lazzaro, 1997; Lazzaro et al., 2003). Greater amounts of solar energy impinging on lakes and higher temperature may further favour primary production (Camargo \& Esteves, 1995; Talling \& Lemoalle, 1998), in accordance with empirical evidence that cyanobacteria more often dominate phytoplankton communities at low latitudes (Komárek, 1985; Pollingher \& Berman, 1991; Talling \& Lemoalle, 1998).

Macrophytes can play an important role in the stabilisation of a clear-water state (Scheffer, 1998), because they may counteract increases in algal turbidity by various mechanisms (Jeppesen et al., 1997). In warm shallow lakes these effects of macrophytes may be even more effective in maintaining water quality, because of the persistence of aquatic plants all the year round and the effective competition between plants and phytoplankton (Mazzeo et al., 2003; Meerhoff et al., 2003). Apart from higher annual water temperatures than in temperate lakes, Mediterranean shallow waterbodies also have significant seasonal water level fluctuations and smaller seasonal changes of light and temperature. Lowering of summer water levels may improve light conditions for macrophytes, which in combination with the higher temperatures and incident solar radiation facilitate over wintering of submerged plants and could stabilise macrophyte dominance and clear-water phases. Overall, data on the ecology of warm shallow lakes are still needed (see review Jeppesen et al., 2003).

By manipulating nutrient availability and fish density in two mesocosm experiments carried out in a shallow Mediterranean lake, we addressed the following questions: (i) is the threshold of nutrients causing eutrophication problems (i.e. phytoplankton blooms) in shallow Mediterranean lakes lower than has been reported from temperate lakes, (ii) can water-level decreases in summer favour macrophyte maintenance and stabilises clear-water phases, (iii) would cyanobacteria dominate phytoplankton communities in both clear and turbid water phases, and (iv) can zooplanktivorous fish influence zooplankton community structure by enhancing the abundance of smaller species and by more strongly affecting algal composition than algal biomass?

\section{Materials and methods}

\section{Study site}

Experiments were carried out in a shallow, 0.5 ha lake, Lake Xeresa, located in the wetland of Xeresa, $65 \mathrm{~km}$ south of Valencia on the east Spanish Mediterranean coast $\left(39^{\circ} 06^{\prime} \mathrm{N}, 0^{\circ} 12^{\prime} \mathrm{W}\right)$. They were part of a series of comparable experiments carried out at six European locations, collectively called the International Mesocosm Experiment (IME). The lake is mainly fed by groundwater and rainfall. Minimum water levels occur during summer because of evaporation and water withdrawal for use in agriculture. Maximum depths are reached during autumn-winter as a result of short, but intense rainfalls. The lake is completely covered by submerged macrophytes, mainly Chara hispida L., together with Chara vulgaris var. vulgaris L. and Chara aspera Deth. ex Willd. and the shores are surrounded by a belt of Phragmites australis (Cav.) Trin. ex. Steud. Nutrient and 
chlorophyll $a$ concentrations in the lake at the start of the experiments were low and similar during the two experimental years: soluble reactive phosphorus (SRP) was below the detection limit of $0.001 \mathrm{mg} \mathrm{L}^{-1}$, total phosphorus (TP) $0.02 \mathrm{mg} \mathrm{L}^{-1}$, nitrate $0.0016 \mathrm{mg} \mathrm{L}^{-1}$, and chlorophyll $a 3-11 \mu \mathrm{g} \mathrm{L}^{-1}$.

\section{Experimental design and sampling}

The IME used the same randomised block design and methods at all six sites (Stephen et al., 2004a). The 1998 experiment lasted 6 weeks (8 June to 14 July) and that in 1999, 7 weeks (14 June to 29 July). Thirty-six mesocosms were made from polyethylene film (125 $\mu \mathrm{m}$ wall thickness) supported at the top and bottom by circular plastic hoops, $1 \mathrm{~m}$ in diameter. The bottom hoops were buried in the sediment of the lake, giving polyethylene cylinders open to the atmosphere and to the lake bottom with its plant community. The top hoops with the mesocosms were supported by a frame of wood and plastic tubing.

In 1998, three fish-density $(0,4$ and $20 \mathrm{~g}$ fresh mass $\mathrm{m}^{-2}$ ) and four nutrient-loading (N-P in $\mathrm{mg} \mathrm{L}^{-1}$ : $0-0,1-0.1,5-0.5$ and 10-1) treatments were applied. In the 1999 experiment, the fish-density treatments were the same as in 1998, and six nutrient treatments covering a narrower range were used (N-P in $\mathrm{mg} \mathrm{L}^{-1}: 0-0,0.3-0.03,0.6-0.06,0.9-0.09$, 1.5-0.15, 30.3). Nutrient loadings were designated N0 (control) to N3 in 1998 and N0 to N5 in 1999. Nutrients were added as mixtures of calcium nitrate and potassium dihydrogen phosphate at weekly intervals. Adjustments were made in amounts added to account for drops in water level so as to keep concentrations achieved broadly in line with those in other experiments of the IME.

The fish species used was the mosquitofish, Gambusia holbrooki Girard (ex Agassiz), which is an ovoviviparous visual predator on zooplankton, widely distributed in the lake, as well as in other Spanish shallow lakes (Blanco et al., 2003). In 1998, fish comprised only males, while in 1999 males and females were used. During the experiment, the enclosures were visually checked twice a week and dead fish replaced, although this was infrequent after the first week. Samples in the mesocosms, and an additional sample from the open lake, were taken at weekly intervals. Sampling started a week before fish and nutrients were added to monitor initial condi- tions. There were no significant differences (one-way ANOVA) in water chemistry, planktonic communities and macrophyte coverage among the mesocosms at the start of the experiments.

\section{Water chemistry}

The physico-chemical variables measured were temperature, $\mathrm{pH}$, total alkalinity, total suspended solids (TSS), TP, SRP, nitrate and ammonium. Alkalinity and TSS were measured in 1998 only. Zooplankton and phytoplankton samples were taken with a tube sampler integrating over the whole water column. Two zooplankton sub-samples were preserved: $3 \mathrm{~L}$ of water were passed through a $25-\mu \mathrm{m}$ mesh for rotifers and nauplii, and $7 \mathrm{~L}$ were passed through a $50-\mu \mathrm{m}$ mesh for copepods and cladocerans. Water used for analysing phytoplankton was not passed through a mesh screen.

Planktonic chlorophyll $a$ was extracted from GF/F filtered samples into $90 \%$ ethanol and measured spectrophotometrically. Three periphyton samples were randomly taken in each enclosure in the pretreatment week and at the end of the experiments. Periphytic algae attached to submerged plants were detached by shaking. Periphytic chlorophyll $a$ was extracted and determined with similar method than phytoplanktonic chlorophyll a. After removing periphyton, plants were dried and weighed. At the end of the experiments, all the macrophytes from within the mesocosms were cut at the sediment surface, identified and dried and weighed.

Three samples of zoobenthos were randomly taken in each enclosure in the pretreatment week, and at the end of the experiment in 1998, with a 5-cm diameter tube sampler. Total biomass of the benthos was determined before preservation and subsequent counting.

\section{Data analysis}

Pretreatment data sets were analysed by one-way ANOVA. Time-weighted averages were calculated from the time data series and tested by two-way ANOVA. Where significant differences were found, Tukey' tests was used to illuminate specific differences between treatments. Weighted averaging gives greater emphasis to data points obtained with increasing time after the start of the treatments. Further 
details on the methodology and statistical analyses can be found in Stephen et al. $(2004 \mathrm{a}, \mathrm{b})$.

\section{Results}

\section{Physico-chemistry}

Water depth gradually changed in the lake and mesocosms, from 80 to $58 \mathrm{~cm}$ during 1998 and from 78 to $26 \mathrm{~cm}$ during 1999. In both years, rates doubled during July compared with June (2-4 cm per week in June and 6-8 cm per week in July).Water temperature ranged from 26 to $34{ }^{\circ} \mathrm{C}$ during the experiments, with means among sampling weeks in 1998 of $26-32{ }^{\circ} \mathrm{C}$ and in 1999 of $27-32{ }^{\circ} \mathrm{C}$. Conductivity increased as summer advanced, from 1.5 to $3 \mathrm{mS} \mathrm{cm}^{-1}$ in 1998 and from 2 to $3 \mathrm{mS} \mathrm{cm}^{-1}$ in 1999. It rose more in the mesocosms than in the lake $\left(1.5-2 \mathrm{mS} \mathrm{cm}^{-1}\right.$ in 1998 and $1.5-2.4 \mathrm{mS} \mathrm{cm}^{-1}$ in 1999). Lake water had a high alkalinity, around 3 meq $\mathrm{L}^{-1}$, and it increased in the mesocosms to $4-5$ meq $\mathrm{L}^{-1}$ and even slightly higher in the highest nutrient treatments (Table 1). Nitrate and phosphorus concentrations in the water column increased in relation to the fertilisation levels (Table 2). SRP concentrations showed only a moderate increase with fertilisation, owing to biological uptake and co-precipitation of phosphates with carbonates. None of the chemical variables analysed was affected by planktivorous fish density, except SRP in 1998 with a positive effect (Table 2).

\section{Primary producers: phytoplankton, periphyton and macrophytes}

Phytoplankton composition and biomass from control mesocosms in both experiments were not significantly different from those in the lake ( $t$-test for matched pairs, $P>0.05)$. Therefore, our experimental mesocosms appeared to reproduce reasonably well the natural lake conditions. The total planktonic algal biomass was significantly related to nutrients in both years (Table 2). Phytoplankton biomass increased with nutrient levels. A chlorophyll $a$ threshold of $100 \mu \mathrm{g} \mathrm{L}{ }^{-1}$ was attained around an added external nutrient concentration between 1 and $1.5 \mathrm{mg} \mathrm{L}^{-1} \mathrm{~N}$ and 0.1 and $0.15 \mathrm{mg} \mathrm{L}^{-1} \mathrm{P}$ (Fig. 1). Turbid states in the experiments were well marked by this threshold.

Densities of planktivorous fish affected phytoplankton biomass to a lesser extent than its composition (Table 2). In 1999, there was a significantly higher presence of non-heterocystous filamentous cyanobacteria in mesocosms without fish $(P<0.001$;

Table 1 Overall treatment mean values of time-weighted averages of water chemical parameters measured in mesocosm during experiments in 1998 and 1999

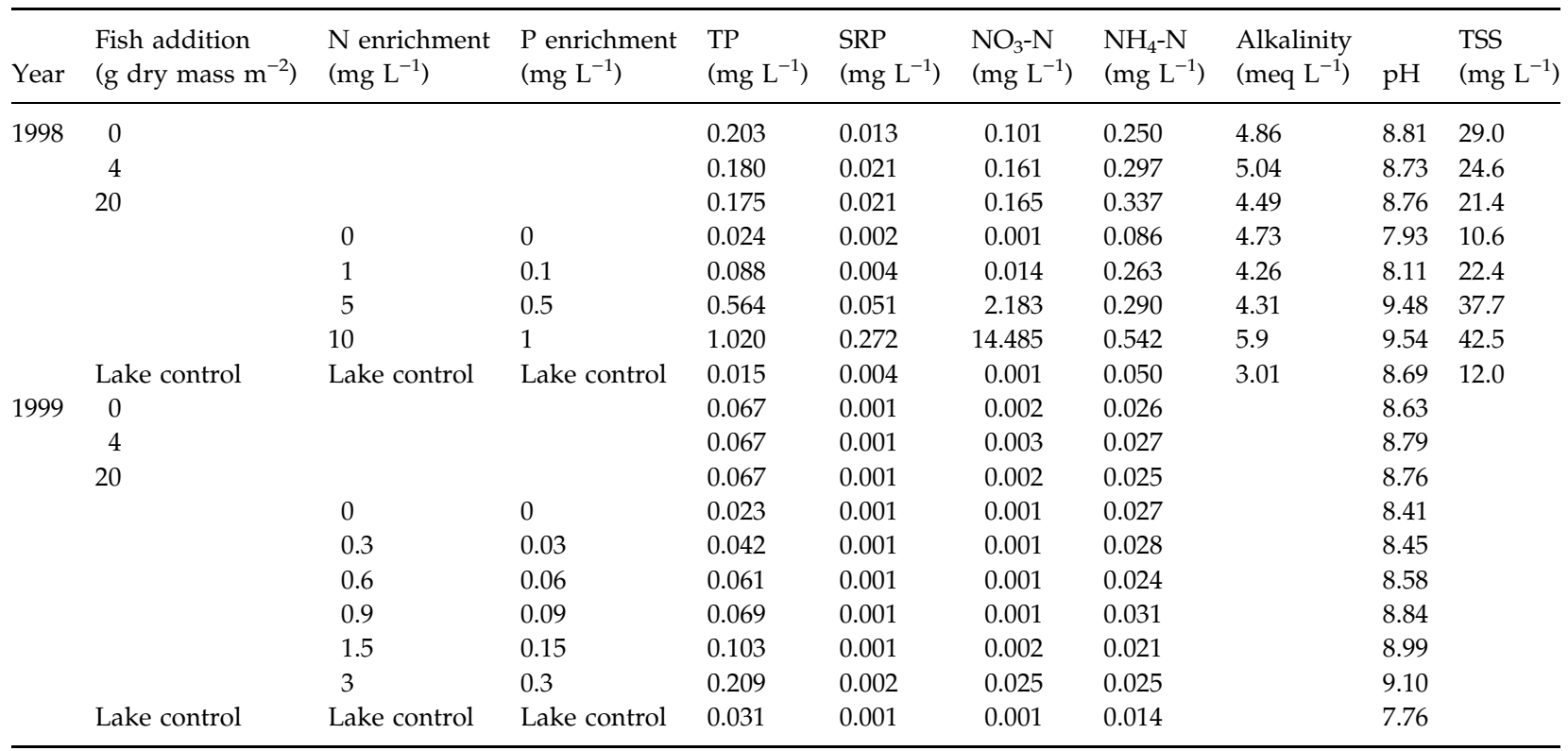

Data from the open lake are also included.

TP, total phosphorus; SRP, soluble reactive phosphorus; TSS, total suspended solids. 
Table 2 ANOVA summary of time-weighted averages of the main variables measured in 1998 and 1999

\begin{tabular}{|c|c|c|c|c|c|c|}
\hline \multirow[b]{2}{*}{ Dependent variable } & \multicolumn{2}{|c|}{ Fish $(F)$} & \multicolumn{2}{|c|}{$\begin{array}{l}\text { Nutrients } \\
\text { (N) }\end{array}$} & \multicolumn{2}{|l|}{$\mathrm{F} \times \mathrm{N}$} \\
\hline & 1998 & 1999 & 1998 & 1999 & 1998 & 1999 \\
\hline $\mathrm{TP}$ & n.s. & n.s. & $* * *$ & $* * *$ & n.s. & n.s. \\
\hline SRP & * & n.s. & $* * *$ & $* * *$ & * & $* *$ \\
\hline $\mathrm{NO}_{3}-\mathrm{N}$ & n.s. & n.s. & $* * *$ & $* * *$ & n.s. & n.s. \\
\hline $\mathrm{NH}_{4}-\mathrm{N}$ & n.s. & n.s. & $* * *$ & n.s. & n.s. & n.s. \\
\hline Alkalinity & n.s. & $\mathrm{n} / \mathrm{a}$ & $* * *$ & $\mathrm{n} / \mathrm{a}$ & n.s. & $\mathrm{n} / \mathrm{a}$ \\
\hline $\mathrm{pH}$ & n.s. & n.s. & $* * *$ & $* *$ & $* *$ & n.s. \\
\hline TSS & n.s. & $\mathrm{n} / \mathrm{a}$ & $* * *$ & $\mathrm{n} / \mathrm{a}$ & n.s. & $\mathrm{n} / \mathrm{a}$ \\
\hline Planktonic chlorophyll $a$ & * & n.s. & $* * *$ & $* * *$ & n.s. & n.s. \\
\hline Total phytoplankton & n.s. & n.s. & $* * *$ & $* *$ & n.s. & n.s. \\
\hline Total cyanobacteria & n.s. & n.s. & $* * *$ & $*$ & n.s. & n.s. \\
\hline Chroococcal cyanobacteria & n.s. & n.s. & $* * *$ & $* *$ & n.s. & n.s. \\
\hline Filamentous cyanobacteria & n.s. & $* * *$ & $* * *$ & n.s. & n.s. & n.s. \\
\hline Chlorophyceae & n.s. & n.s. & $* * *$ & $* * *$ & n.s. & n.s. \\
\hline Cryptophyceae & n.s. & n.s. & $* * *$ & $* *$ & n.s. & n.s. \\
\hline Bacillariophyceae & n.s. & n.s. & $* * *$ & n.s. & n.s. & n.s. \\
\hline Dinophyceae & n.s. & $* * *$ & n.s. & * & n.s. & n.s. \\
\hline Euglenophyceae & n.s. & n.s. & n.s. & n.s. & n.s. & n.s. \\
\hline GALD $<50 \mu \mathrm{m}$ & n.s. & n.s. & $* * *$ & $* * *$ & n.s. & n.s. \\
\hline GALD $>50 \mu \mathrm{m}$ & n.s. & $* * *$ & $* * *$ & n.s. & n.s. & n.s. \\
\hline $\begin{array}{l}\text { Phytoplankton } \\
\text { diversity index }\end{array}$ & * & n.s. & n.s. & $* * *$ & n.s. & n.s. \\
\hline Periphytic chlorophyll $a$ & n.s. & n.s. & n.s. & $* * *$ & n.s. & n.s. \\
\hline Total zooplankton & $* * *$ & $* *$ & $* * *$ & $* * *$ & n.s. & n.s. \\
\hline Rotifera & $* * *$ & $* *$ & n.s. & $* * *$ & $* *$ & n.s. \\
\hline Cladocera $<500 \mu \mathrm{m}$ & $* * *$ & $* * *$ & n.s. & n.s. & n.s. & n.s. \\
\hline Cladocera $>500 \mu \mathrm{m}$ & $* * *$ & $\mathrm{n} / \mathrm{a}$ & n.s. & $\mathrm{n} / \mathrm{a}$ & n.s. & $\mathrm{n} / \mathrm{a}$ \\
\hline Cyclopoid Copepoda & $* * *$ & $* * *$ & $* *$ & n.s. & n.s. & n.s. \\
\hline Calanoid Copepoda & n.s. & $* *$ & n.s. & n.s. & n.s. & n.s. \\
\hline Nauplii & $* *$ & $* * *$ & $* * *$ & n.s. & n.s. & n.s. \\
\hline Raptorial zooplankters & $* * *$ & $* *$ & $* * *$ & n.s. & n.s. & n.s. \\
\hline Open-water filterers & n.s. & n.s. & $* * *$ & n.s. & * & n.s. \\
\hline Total zoobenthos & n.s. & $\mathrm{n} / \mathrm{a}$ & * & $\mathrm{n} / \mathrm{a}$ & n.s. & $\mathrm{n} / \mathrm{a}$ \\
\hline Chironomidae & n.s. & $\mathrm{n} / \mathrm{a}$ & n.s. & $\mathrm{n} / \mathrm{a}$ & n.s. & $\mathrm{n} / \mathrm{a}$ \\
\hline Oligochaeta & n.s. & $\mathrm{n} / \mathrm{a}$ & n.s. & $\mathrm{n} / \mathrm{a}$ & n.s. & $\mathrm{n} / \mathrm{a}$ \\
\hline
\end{tabular}

${ }^{*} P<0.05,{ }^{* *} P<0.01,{ }^{* * *} P<0.001$, n.s. $=$ not significant, $\mathrm{n} / \mathrm{a}=$ not applicable.

TP, total phosphorus; SRP, soluble reactive phosphorus; TSS, total suspended solids.

Values for phytoplankton groups are biovolumes. Values for zooplankton are biomasses, and those for benthic invertebrates are numbers per square metre.

Table 2). Cyanobacteria were the main algal group during 1999. There was a general trend for chroococcal cyanobacterial species to become dominant towards the end of the 1999 experiment, especially with increasing nutrient levels (Table 2; Figs 2 \& 3). In the fishless mesocosms, zooplankton thus appeared to feed on the abundant edible Chroococcus
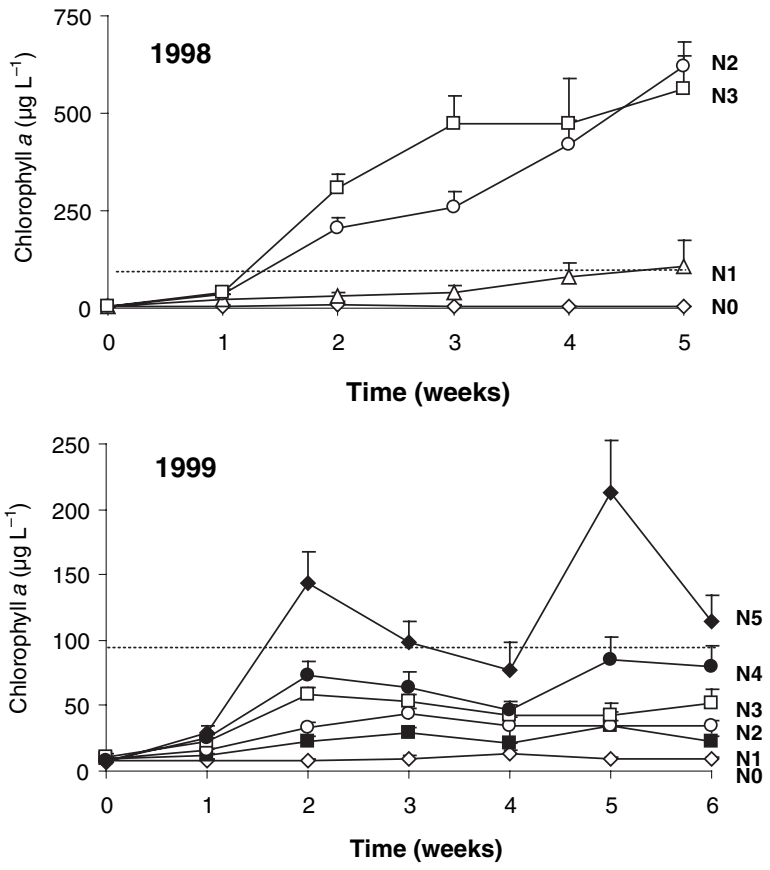

Fig. 1 Changes in phytoplanktonic chlorophyll $a$ concentrations at different nutrient loadings during mesocosm experiments in 1998 and 1999. Week zero refers to samples taken before nutrient and fish additions. Values represent overall treatment mean. The horizontal line shows the chlorophyll $a$ value of $100 \mu \mathrm{g} \mathrm{L} \mathrm{L}^{-1}$.

Vertical lines indicate standard errors.

spp., which may have selected in favour of filamentous cyanobacteria. Consequently, changes in phytoplankton size distributions during 1999 were mostly related to changes in these two main cyanobacterial groups, and larger algae with a Greatest Axial or Linear Dimension (GALD) $>50 \mu \mathrm{m}$ were more prominent in the zero fish treatment (Table 2). In 1999, fish presence also influenced the abundance of dinophytes (Table 2). Peridinium umbonatum Stein, the predominant dinophyte, was small (GALD = $35 \mu \mathrm{m})$, and was significantly more abundant in mesocosms with fish (Table 2). During 1998, there was also an increase, although less important, of chroococcal cyanobacteria during the experiment, while filamentous cyanobacteria were significantly more abundant in the mesocosms at higher nutrient levels (N2 and N3) and again in the fishless mesocoms (Table 2; Fig. 2). In 1998, other algal groups co-dominated with cyanobacteria. In both years, phytoplankton species diversity decreased with increasing nutrient concentrations, although it was only significant in 1999 (Table 2). In 1998, phyto- 

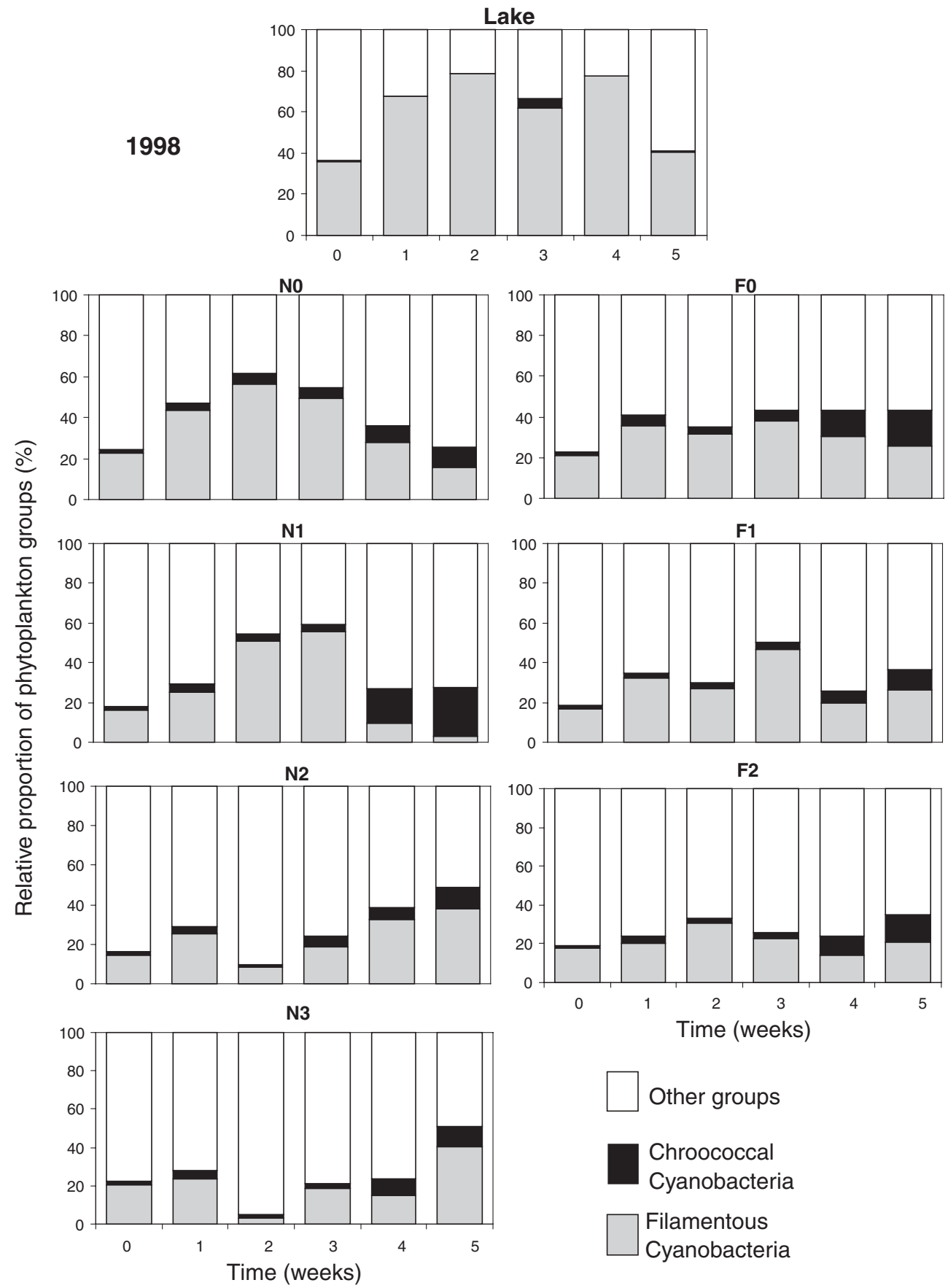

$\square$ Other groups

Chroococcal

Cyanobacteria

Filamentous

Cyanobacteria

Fig. 2 Percentage biovolume of the main phytoplankton groups at different nutrient loadings and fish densities in mesocosms during the experiment in 1998. Bars represent overall treatment mean values.

plankton diversity also decreased at the highest fish density (Table 2).

Periphytic algal biomass was significantly related to nutrients in 1999 (Table 2), when periphytic chlorophyll $a$ increased exponentially while charophyte biomass declined significantly at nutrient additions above $0.6 \mathrm{mg} \mathrm{L}^{-1} \mathrm{~N}$ and $0.06 \mathrm{mg} \mathrm{L}^{-1} \mathrm{P} \quad(P<0.05$; Fig. 4), despite improved light availability through increasingly lowered water levels. In both experiments, the initial macrophyte biomass in the pretreat- 

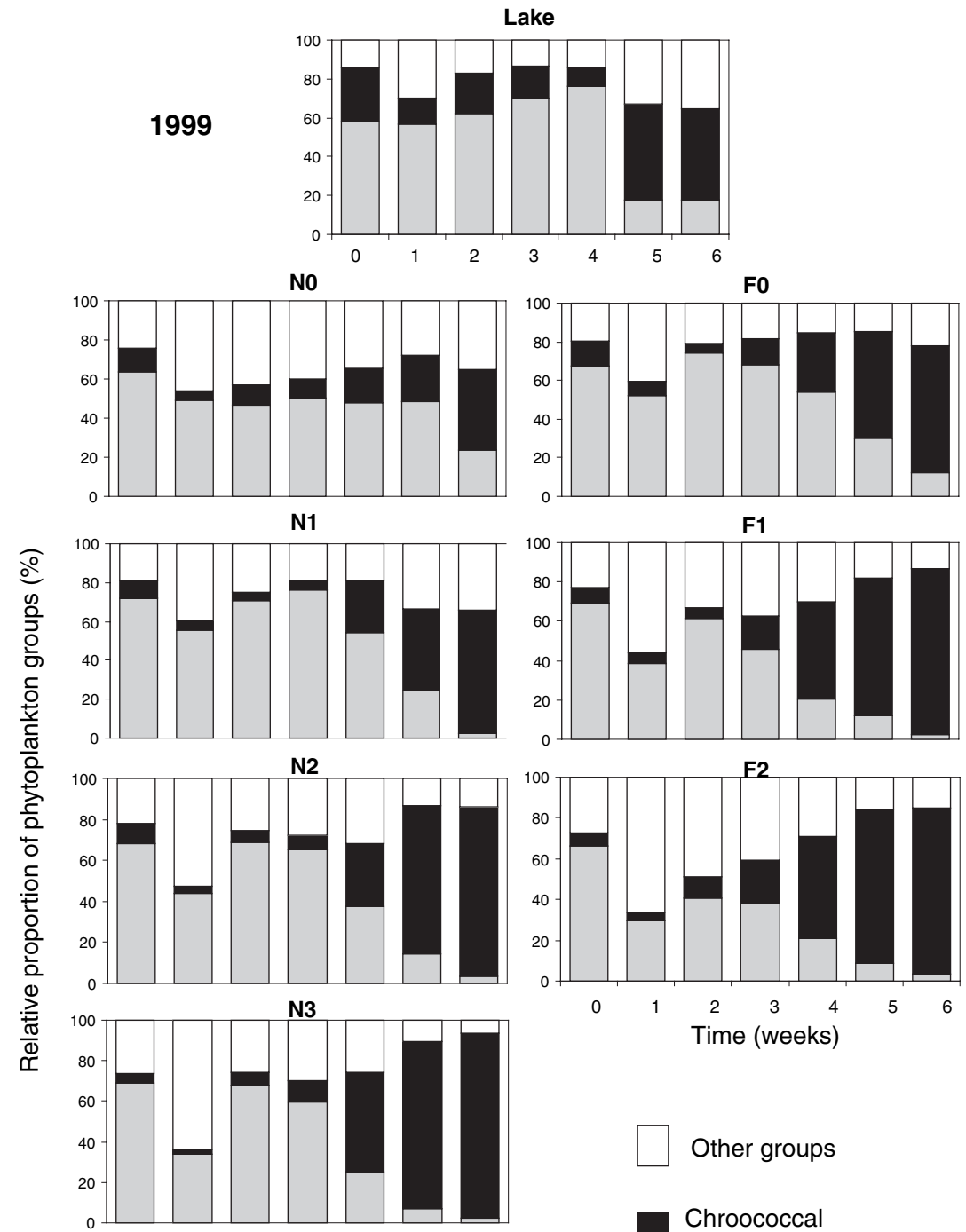

Fig. 3 Percentage biovolume of the main phytoplankton groups at different nutrient loadings and fish densities in mesocosms during the experiment in 1999. Bars represent overall treatment mean values.
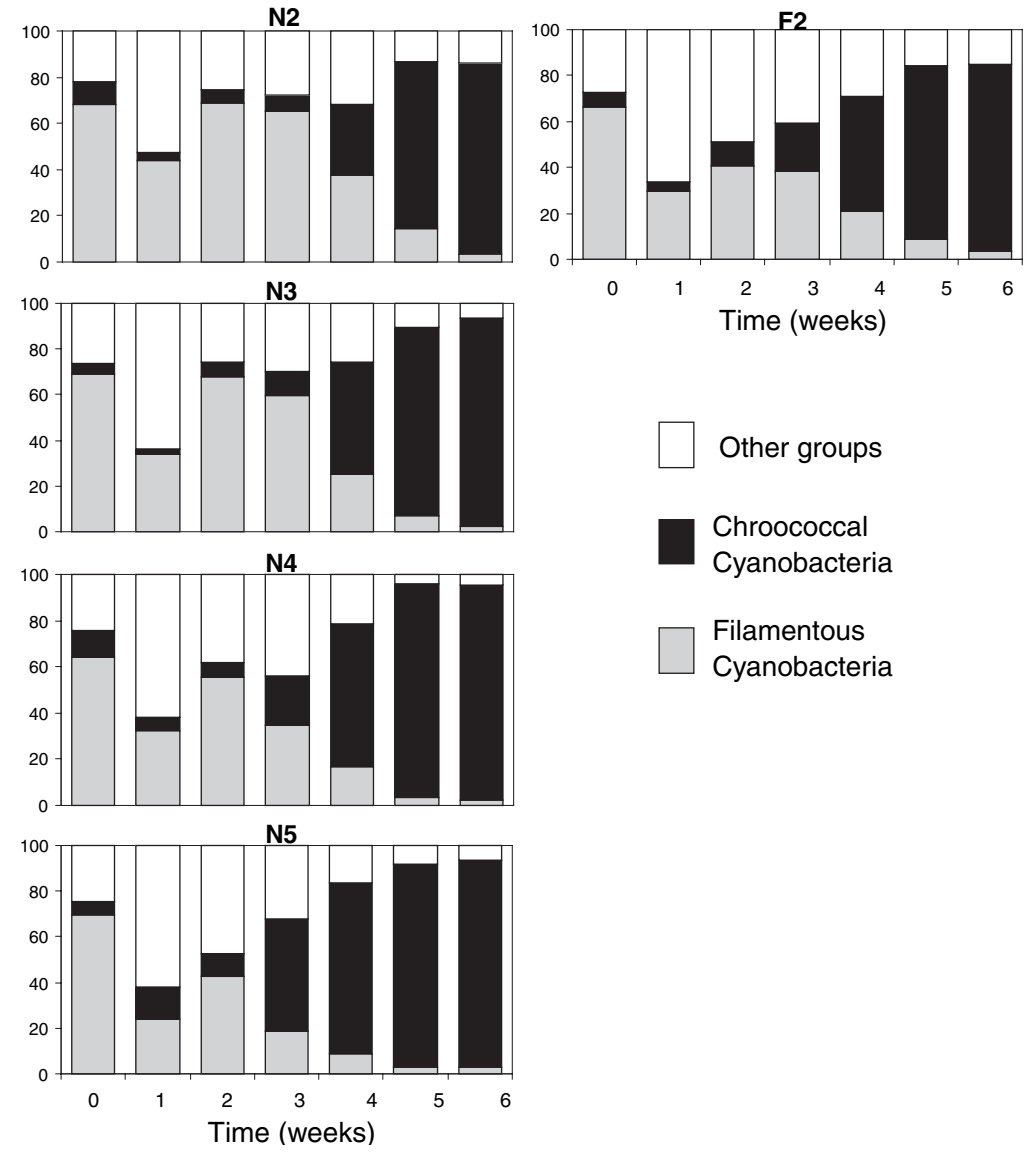

ment week was similar (mean of $6 \mathrm{~g}$ of dry macrophyte mass per sample). During 1998, there was also an increase of periphyton with nutrient addition
(Fig. 4), but the turbid phase was rapidly reached at the highest nutrient levels after the first week of fertilisation (N2 and N3; Fig. 1), and macrophytes 

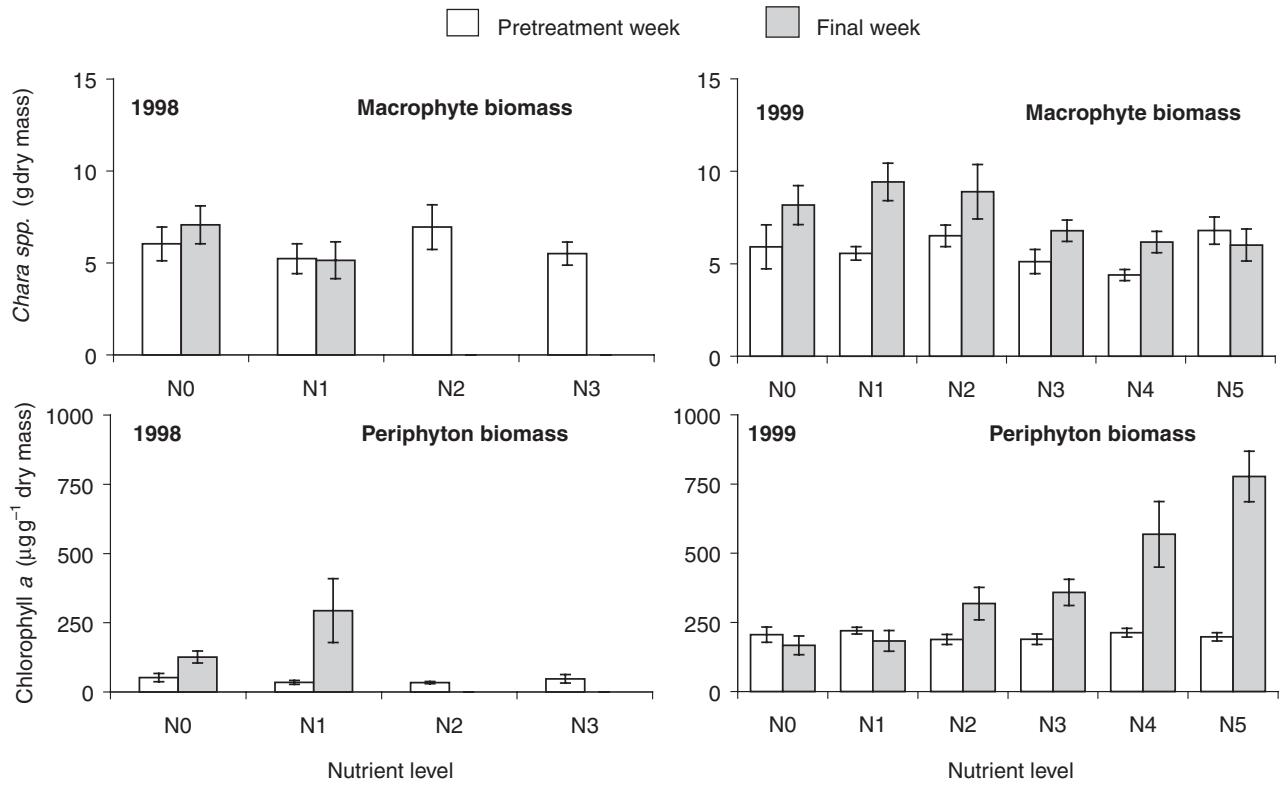

Fig. 4 Mean biomasses of submerged macrophytes and periphyton at different nutrient loadings during mesocosm experiments in 1998 and 1999. Macrophyte biomass is expressed as dry mass of Chara spp. per Kornijow sample. Periphyton biomass is given as mean chlorophyll $a$ per gram of charophyte dry mass. Bars are treatment means and vertical lines are \pm 1 SE.

disappeared before the end of the experiment (Fig. 4). Fish did not significantly influence macrophyte or periphyton biomass (Table 2).

\section{Secondary producers: zooplankton and macroinvertebrates}

Zooplankton biomass was slightly higher in 1999 than in 1998, and composition slightly different between experiments. The general trends of zooplankton dynamics and species composition were comparable between the lake and control mesocosms during the experiments. Initial zooplankton biomass was similar in both years (average of $62.5 \mu \mathrm{g} \mathrm{L}^{-1}$ in pretreatment mesocosms), but composition differed. In 1998, rotifers accounted for $6 \%$, cladocerans for $9 \%$ and copepods for $85 \%$ of the initial biomass, whereas corresponding percentages in 1999 were 27, 1 and $72 \%$. In 1999, the relative biomass of rotifer species that can be associated to aquatic plants (Lecane, Lepadella, Colurela, Cephalodella) rose greatly in both the lake and mesocosms as the water level gradually dropped. Cyclopoids dominated at the start of both experiments, whereas calanoid copepods were scarce (Table 3). Acanthocyclops robustus Sars was the main cyclopoid species in both years. Cladocerans were mainly represented, by the medium-
Table 3 Time-weighted averages of calanoid biomass $\left(\mu \mathrm{g} \mathrm{L}{ }^{-1}\right)$ during mesocosm experiments in 1998 and 1999

\begin{tabular}{|c|c|c|c|c|}
\hline \multirow[b]{2}{*}{ Year } & \multirow{2}{*}{$\begin{array}{l}\text { Nutrient } \\
\text { enrichment } \\
\text { level }\end{array}$} & \multicolumn{3}{|c|}{ Fish density level } \\
\hline & & F0 & $\mathrm{F} 1$ & $\mathrm{~F} 2$ \\
\hline \multirow[t]{4}{*}{1998} & No & 3.5 & 0.0 & 0.1 \\
\hline & N1 & 4.0 & 2.5 & 0.01 \\
\hline & N2 & 0.2 & 0.3 & 0.2 \\
\hline & N3 & 0.1 & 0.0 & 0.0 \\
\hline \multirow[t]{6}{*}{1999} & No & 1.5 & 0.2 & 0.0 \\
\hline & N1 & 0.01 & 0.0 & 0.0 \\
\hline & N2 & 0.8 & 0.0 & 0.0 \\
\hline & N3 & 0.3 & 0.1 & 0.0 \\
\hline & N4 & 2.4 & 0.1 & 0.0 \\
\hline & N5 & 0.0 & 0.4 & 0.0 \\
\hline
\end{tabular}

The time-weighted averages in the lake were $13 \mu \mathrm{g} \mathrm{L} \mathrm{L}^{-1}$ in 1998 and $1 \mu \mathrm{g} \mathrm{L}^{-1}$ in 1999, and the mean values for all 36 mesocosms during the pretreatment sampling were 17 and $2 \mu \mathrm{g} \mathrm{L}^{-1}$ in 1998 and 1999, respectively.

sized Ceriodaphnia reticulata Jurine in both years, but in 1998 cladocerans, such as the large Simocephalus vetulus Müller and the small Chydorus sphaericus Müller were also abundant (Fig. 5). The rotifers were mainly represented by the planktonic genera Polyarthra, Hexarthra, Trichocerca, Anuraeopsis and Proalides, but there were also species that are typically plant-associated. 

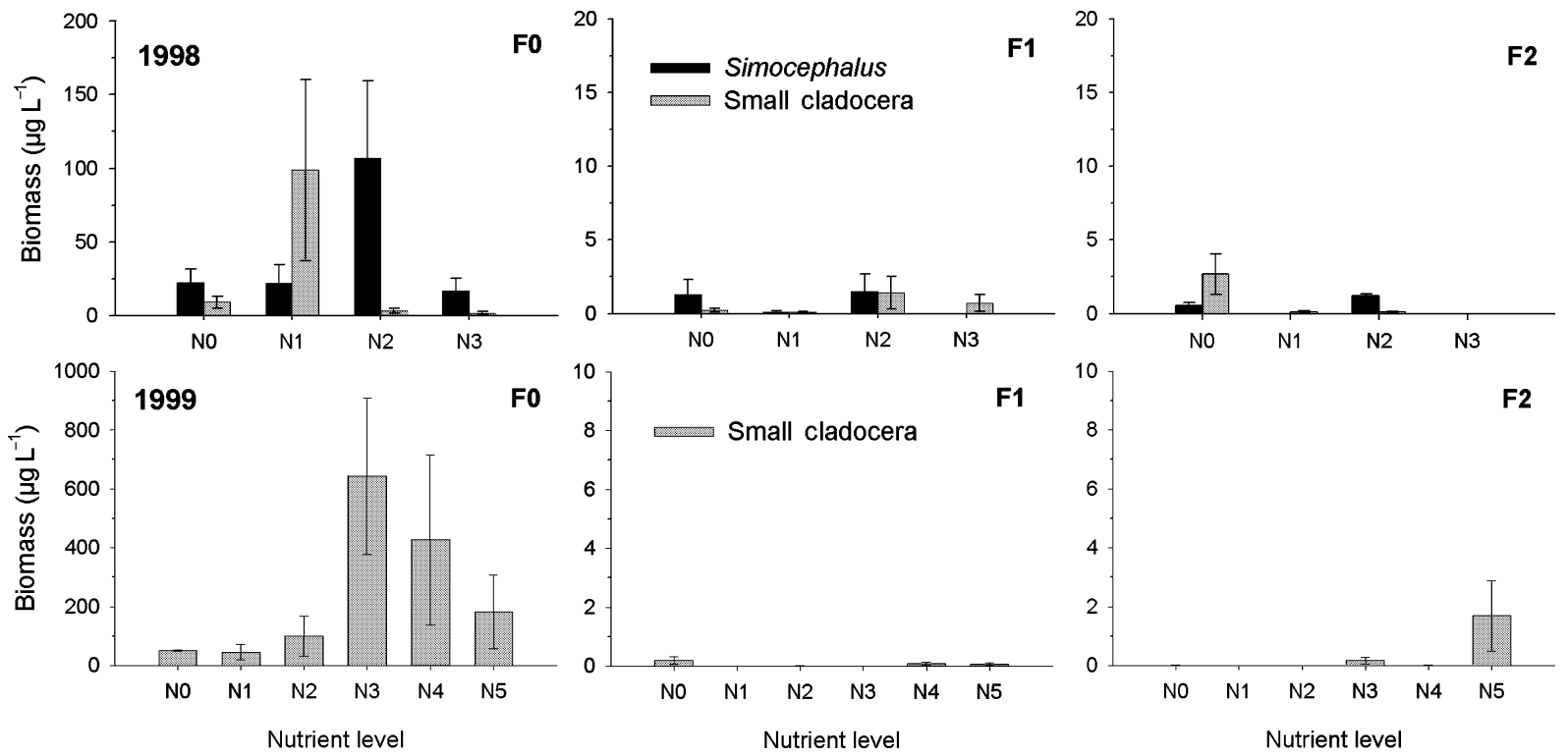

Fig. 5 Response of Cladoceran biomass to nutrient and fish additions in mesocosm experiments in 1998 (up) and 1999 (down). Bars represent time-weighted averages of biomass for each nutrient and fish treatment. Vertical lines are \pm 1 SE.

In both experiments, there were significant effects of fish on zooplankton biomass and community structure (Table 2). The effect was negative for crustaceans, whereas rotifer biomass increased with increased fish densities. Small and medium-sized cladocerans were essentially restricted to the fishless mesocosms in both years, as was the larger Simocephalus (Fig. 5). Similarly, in both experiments, cyclopoid adults and copepodites were almost absent and numbers of nauplii were much reduced at the highest fish density (Fig. 6). In 1998, a slightly higher proportion of nauplii was present at the intermediate fish density than in mesocosms without fish. Calanoid copepods were also depressed in mesocosms with fish in both years, although not significantly so in 1998 (Tables 2 and 3). Rotifer biomass increased in the enclosures with fish, and more so at the highest fish density (Figs 6 \& 7). An inverse relationship was observed between planktonic rotifers and cyclopoid biomass, especially adults and copepodites (Fig. 6). Cyclopoids may prey upon rotifers and nauplii compete with rotifers for resources.

Nutrient addition had a positive significant effect on total zooplankton biomass, except at the highest nutrient level in 1998. There were marked differences among separate groups (Table 2). Nutrients had no significant effect on calanoids or cladocerans (Table 2). Calanoids were also more abundant in the lake during the experimental period and in the pretreatment sampling (Table 3). In 1998, a negative effect on calanoid biomass was observed with nutrient addition in the fishless mesocosms (Table 3).

Cladoceran biomass responded to intermediate nutrient additions (Fig. 5). Nutrient levels of 0.9$1.5 \mathrm{mg} \mathrm{L}^{-1} \mathrm{~N}$ and $0.09-0.15 \mathrm{mg} \mathrm{L}^{-1} \mathrm{P}$ had a positive effect on Ceriodaphnia, and Simocephalus attained a maximum biomass at $5 \mathrm{mg} \mathrm{L}^{-1} \mathrm{~N}$ and $0.5 \mathrm{mg} \mathrm{L}^{-1} \mathrm{P}$ (Fig. 5). Similarly, cyclopoids in all their stages showed a general trend of increases at intermediate nutrient levels (Fig. 6). Their response was significant in 1998 when they were dominant and very abundant (Table 2), but in 1999 nutrient addition only influenced their biomass in the fishless mesocosms (Fig. 6). A significant interaction effect of fish and nutrients on planktonic rotifer biomass was noted in 1998 (Table 2), perhaps owing to the aforementioned inverse relationship between planktonic rotifer and cyclopoid biomass, reaching peaks at intermediate nutrient levels (Fig. 6). Rotifer species normally classified as plant-associated exhibited an opposite trend to that of the planktonic species. In 1999, plant-associated species were dominant in the plankton samples and nutrient additions significantly increased their biomass in all mesocosms, especially in those with fish (Fig. 7). In 1998, an increase with nutrients was only observed at the highest fish density. 

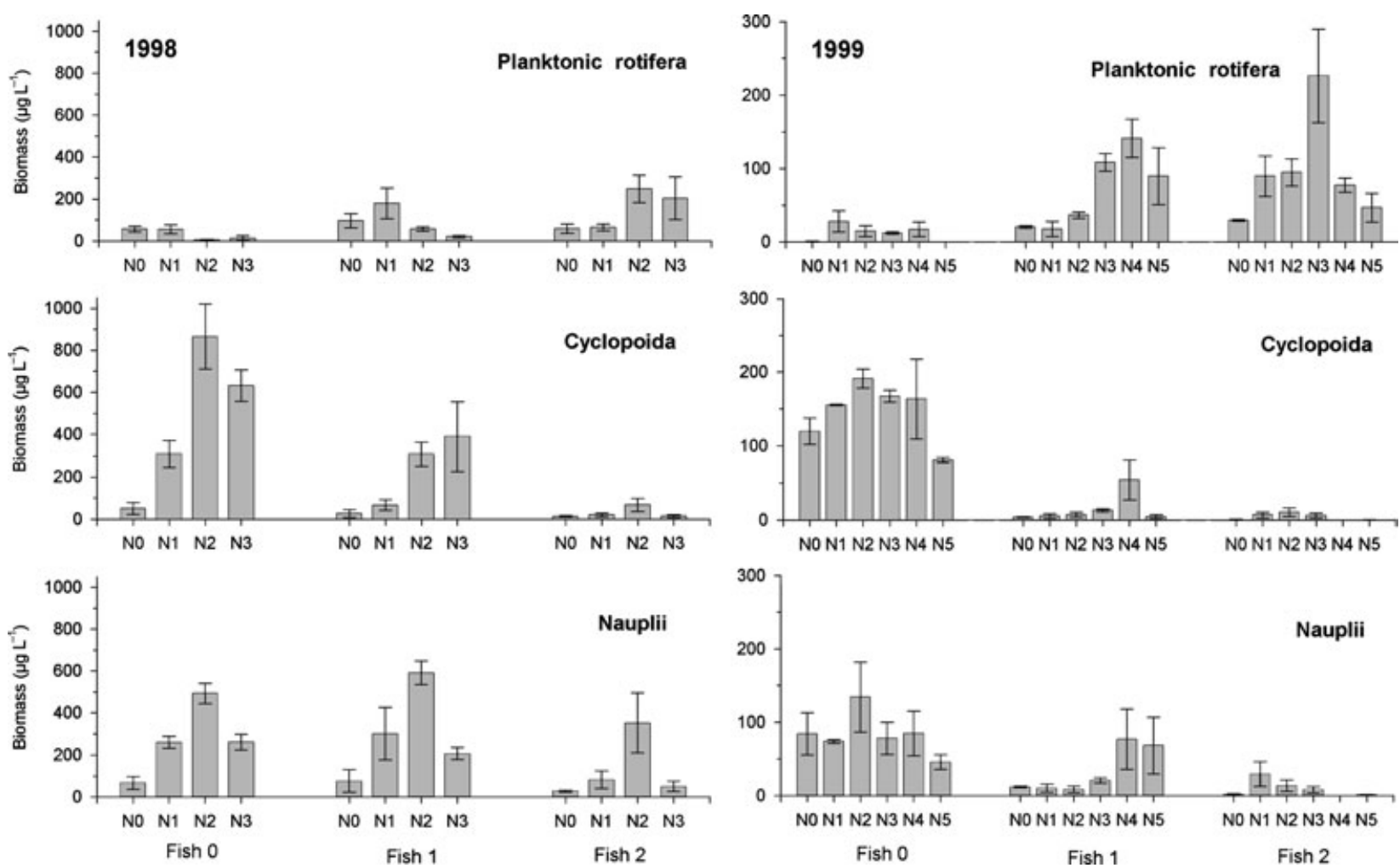

Fig. 6 Response of cyclopoid copepods (nauplii and copepodites plus adults) and planktonic rotifers to nutrient and fish additions during mesocosm experiments in 1998 (left) and 1999 (right). Bars are time-weighted averages of biomass at each nutrient and fish treatment. Vertical lines are $\pm 1 \mathrm{SE}$.

Benthic macroinvertebrates in 1998 consisted mainly of chironomids. Numbers of individuals in these samples did not respond to the presence of fish, but showed a positive relationship with nutrients, with higher numbers at intermediate nutrient levels (N1) (Table 2).

\section{Discussion}

There were significant relationships between algae, nutrients and water transparency, which suggests that nutrients controlled biomass of phytoplankton and periphyton, while zooplankton regulated by planktivorous fish may have influenced the relative proportions of the dominant phytoplankton species. The threshold of nutrient levels resulting in turbid water and loss of submerged plants was lower than that often given for temperate northern lakes, where reduction of algal turbidity and re-establishment of submerged macrophytes has been suggested generally to occurs when external loading is below 0.5$2 \mathrm{~g} \mathrm{TP} \mathrm{m}^{-2}$ year $^{-1}$, equivalent to an in-lake P summer concentration of $0.08-0.15 \mathrm{mg} \mathrm{L}^{-1}$ (Jeppesen et al., 1990). Benndorf (1990) proposed a P-loading threshold of $0.6 \mathrm{~g} \mathrm{TP} \mathrm{m}^{-2}$ year $^{-1}$, below which top-down effects of zooplankton on phytoplankton become effective, but dynamics of P-reserves in macrophytes and fish, as well as lake characteristics, may alter this predicted threshold. For instance, Jeppesen et al. (1990) reported that submerged macrophytes were absent in Danish lakes $>10$ ha with $\mathrm{P}$ concentrations of $0.25-0.3 \mathrm{mg} \mathrm{L}^{-1}$, but were still abundant at $0.65 \mathrm{mg}$ $\mathrm{P} \mathrm{L}^{-1}$ in lakes $<3 \mathrm{ha}$, owing to more favourable conditions for macrophyte growth in the smaller lakes.

According to our results, an algal turbid state was obtained in a few weeks with inorganic P loadings between 0.1 and $0.15 \mathrm{mg} \mathrm{L}^{-1}$ or TP concentrations in the lake of $0.09-0.1 \mathrm{mg} \mathrm{L}^{-1}$ (Fig. 1). Therefore, for shallow hardwater lakes in Mediterranean climate conditions, nutrient loadings equivalent to these concentrations may represent an upper limit to avoid shifts from clear-water to a turbid state. Furthermore, this nutrient threshold will not generally act to 

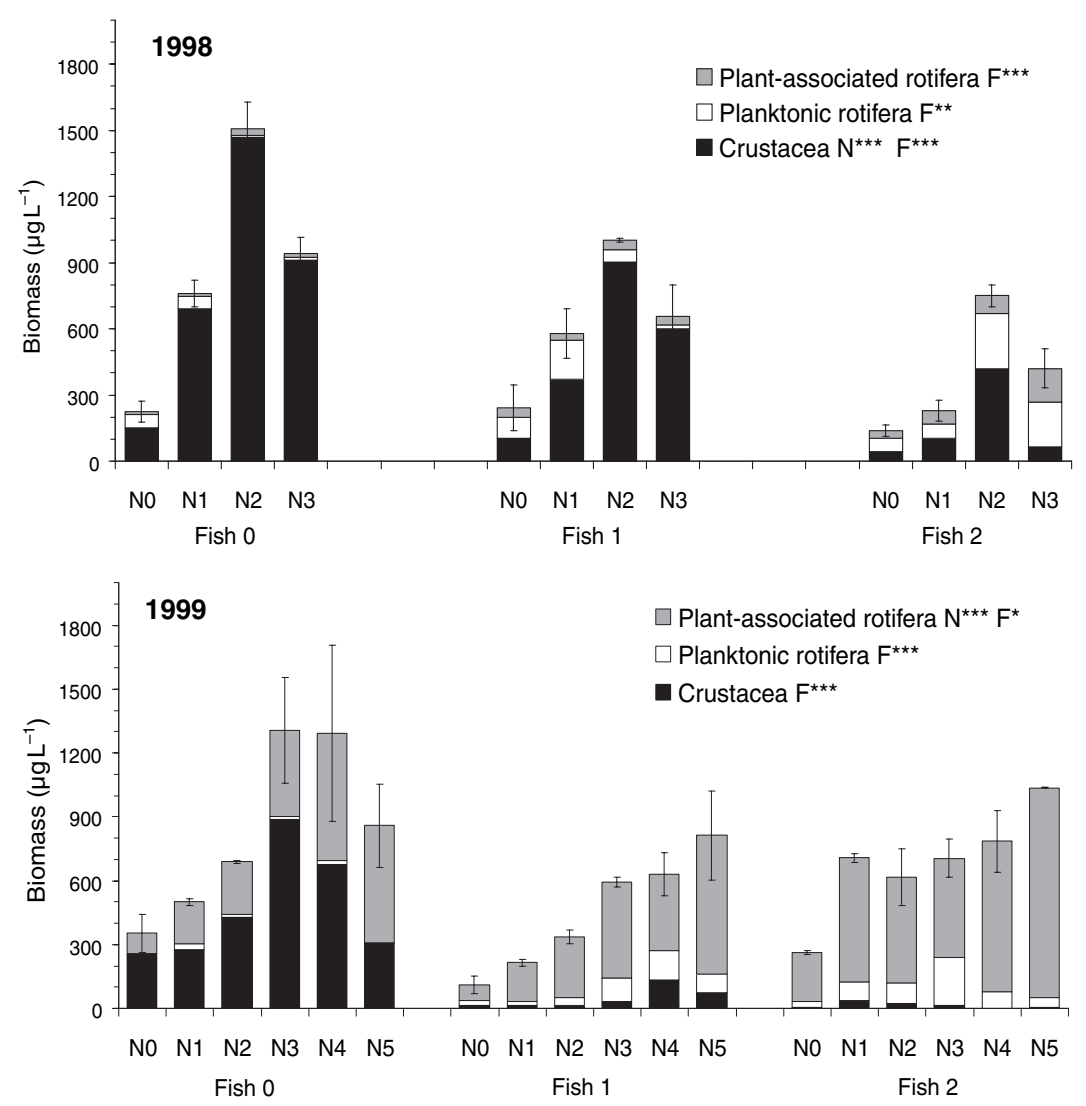

Fig. 7 Total microinvertebrate biomass and its distribution among crustaceans, planktonic rotifers and plant-associated rotifer species in mesocosm experiments in 1998 and 1999. Bars are time-weighted averages of biomass at each nutrient and fish treatment. Vertical lines are $\pm 1 \mathrm{SE}$ for total biomass. Asterisks represent ANOVA levels of significance, ${ }^{*} P<0.05,{ }^{* *} P<0.01,{ }^{* * *} P<0.001$, for fish (F) and nutrients (N).

preserve submerged macrophytes, because characeans, which are highly sensitive to eutrophication (Blindow, 1992), started to decline in our experiments with nutrient loadings equivalent to $0.06 \mathrm{mg} \mathrm{L}^{-1} \mathrm{P}$. This value agrees with findings by Forsberg (1964) in experimental work with $C$. hispida, our dominant species. Algal turbidity and exponential increases in periphyton biomass with fertilisation probably induced submerged macrophyte decline (Jeppesen et al., 1997; Weisner, Strand \& Sandsten, 1997). The relationship between transparency and submerged vegetation is evident, especially with charophytes. Studies in The Netherlands have reported a critical Secchi depth of about $0.4 \mathrm{~m}$ for the disappearance or restablishment of charophytes (Van den Berg, Scheffer \& Coops, 1998; Van den Berg et al., 1999), while there were two critical TP levels, $0.3 \mathrm{mg} \mathrm{L}^{-1}$ for loss and $0.1 \mathrm{mg} \mathrm{L}^{-1}$ for their return (Van den Berg et al., 1998, 1999). The potentially positive effect of the reduction in water depth on characean maintenance in our experiments was partly compensated by higher periphyton growth and turbidity caused by phytoplankton as nutrient concentrations increased. Our observations agree with the critical value of $0.3 \mathrm{mg} \mathrm{L}^{-1} \mathrm{P}$ suggested by Van den Berg et al. (1999) for stonewort loss, while for their restoration a lower value $\left(0.06 \mathrm{mg} \mathrm{L}^{-1}\right)$ is probably required. This agrees with observations in several shallow lakes in southeast Spain, where a stable turbid state (about $100 \mu \mathrm{g} \mathrm{L}^{-1}$ of chlorophyll a) corresponds well with in-lake $\mathrm{P}$ concentrations $\geq 0.1 \mathrm{mg} \mathrm{L}^{-1}$, while a stable macrophyte-transparent state is recorded with $\mathrm{P}$ values ten-fold lower (S. Romo \& R. Miracle, unpublished data). Thus, phosphate loadings giving concentrations $\leq 0.05 \mathrm{mg} \mathrm{L}^{-1}$ are suggested as the critical threshold to avoid algal turbid states and maintain submerged macrophytes in Mediterranean shallow lakes. 
Low water level led to changes in plankton community structure, for instance the succession from filamentous to small chroococcal cyanobacterial species, and the presence of higher numbers of plantassociated rotifer species. Some of these results are similar to those obtained in a shallow lake with large water level fluctuations in the eastern Baltic region (Noges \& Noges, 1999). In our experiments, low water levels improved light conditions, which could be an important factor favouring chroococcal cyanobacteria. The biomass of chroococcal cyanobacteria increased at intermediate nutrient levels and the presence of zooplanktivorous fish (related to abundance of small zooplankton), while filamentous cyanophytes were more abundant at higher nutrient levels, turbidity and in the fishless mesocosms with presence of crustaceans. According to Vanni (1987), in enriched systems, size-selective predation by fish on zooplankton can support maintenance of edible phytoplankton, which provides a good food source for smaller zooplankton. Our results also agree with those of Hurlbert, Zedler \& Fairbanks (1972) who observed dominance of tiny blue-green algae in Gambusia pools in southern California. Similarly, Gambusia feeding also altered P cycling by enhancing concentrations of SRP.

Experimental and field observational data have shown that some filamentous algae are shade-adapted and may dominate turbid eutrophic shallow lakes (Nicklisch \& Kohl, 1989; Scheffer et al., 1997). Our experimental data support the hypothesis that Mediterranean shallow freshwater lakes are suitable habitats for cyanobacteria in both clear and turbid phases, and across a wide range of nutrient levels (0.02$1 \mathrm{mg} \mathrm{L}^{-1} \mathrm{TP}$; Figs $2 \& 3$ ). Although cyanobacteria may be dominant throughout the year in some temperate eutrophic lakes (Sas, 1989), their seasonal pattern in cooler climates depends especially on winter conditions, because cyanobacteria rarely overwinter in large numbers at low temperatures. The mild winters of the Mediterranean Spanish coast (average winter water temperature of $12{ }^{\circ} \mathrm{C}$ ), in contrast, allow for their presence all the year round (Romo \& Miracle, 1993a). Cyanobacteria achieve maximum growth at higher temperatures than other algal groups (Reynolds, 1984; Romo \& Miracle, 1993b; Romo, 1994), which is consistent with some observations that cyanobacteria are better represented in tropical and sub-tropical freshwaters (Komárek, 1985; Pollingher \& Berman, 1991; Talling \& Lemoalle, 1998). Further- more, it has been reported from some temperate lakes that an increase in water temperature lengthened the tenure of filamentous algal blooms (Bailey-Watts \& Kirika, 1999). Thus, temperature dependencies of cyanobacteria appear to be a critical factor accounting for phytoplankton deviations in responses to nutrient enrichment in Mediterranean shallow lakes compared with temperate shallow lakes.

Concerning top-down effects, our results indicate that planktivorous fish markedly influence zooplankton community structure in shallow Mediterranean lakes, removing larger zooplankters and increasing the abundance of smaller species, particularly rotifers. This affected algal community composition more than algal biomass. Removal of cladocerans by mosquitofish was complete even at the lower fish density, whereas cyclopoid copepods were less affected by fish, especially at intermediate nutrient levels. Escape movements of Cladocera are less effective than those of copepods (Drenner \& MacComas, 1980; Gliwicz, 2002). Similar results have been reported in enclosure experiments involving other fish species (Bertolo et al., 2000).

The ratio of crustacean biomass to phytoplankton biomass was significantly lower in our experiments compared with other mesocosm experiments in shallow temperate lakes carried out as part of the pan-European IME project (Vakkilainen et al., 2004). This result underlines the resistance of our Mediterranean lake to remain in a turbid state with zooplankton exerting only a weak control on algal biomass, as a consequence of intense fish predation. This finding agrees with observations for tropical and subtropical shallow lakes (Fernando, 1994; Lazzaro, 1997; Lazzaro et al., 2003). A higher diversity and biomass of zooplankton was found in mesocosms without fish, at intermediate nutrient levels and in the presence of macrophytes. Our results also indicate that when submerged macrophyte density is high (e.g. in 1999), zooplankton filter feeders, such as rotifers in characean beds, can be favoured over omnivorous and more raptorial copepods, and even the overlying water can be dominated by normally plant-associated rotifer species. In 1999, macrophytes also favoured a higher biomass of Cladocera in the fishless mesocosms (Fig. 5). Although characean beds are considered good refuges for Crustacea (Lauridsen et al., 1996; Jeppesen et al., 1997), Crustacea did not escape mosquitofish 
predation, probably owing to lower water volume and the presence of female mosquitofish, which appear to be highly efficient in selecting for Crustacea and especially cladocerans (Blanco, Romo \& Villena, 2004).

Benthic macroinvertebrates were not significantly affected by fish, perhaps owing to alternative prey and the planktonic habits of mosquitofish (Blanco et al., 2004). The response of macroinvertebrates to nutrients was complex, maybe because of the decomposition of macrophytes at the highest nutrient loadings in 1998 (R. Miracle \& S. Romo, unpublished data).

In conclusion, the thresholds of nutrient loading and in-lake $P$ required to avoid a turbid state were lower than those reported from temperate shallow lakes. Phosphate loadings giving concentrations $\leq 0.05 \mathrm{mg} \mathrm{L}^{-1}$ are suggested as the threshold to avoid algal turbid states and maintain submerged macrophytes in Mediterranean shallow lakes. Cyanobacteria dominated in both clear and turbid phases, and across a wide range of nutrient levels. Zooplanktivorous fish influenced zooplankton community structure by enhancing the abundance, especially of rotifers. Thus, our mesocosms experiments on the food webs in a Mediterranean shallow lake revealed differences in responses to nutrient addition and the presence of planktivorous fish compared with temperate shallow lakes and resemble in many respects to subtropical and tropical shallow lakes.

\section{Acknowledgments}

We are especially grateful to Dr Santos Cirujano for characean species identification, Dr Teresa Alfonso for dealing with rotifer samples, María Sahuquillo for her useful help in many stages at the International Mesocosm Experiment, and Iván Arribas for statistical advice. We would also like to thank Miguel Angel Mahiques, Susana Martínez, Virginia Salavert, José Miravet, Antonio Picazo, Dolores Sendra, José Poquet, Raúl de Pedro, Ivan Maña, Antonio Olivas, Consuelo García, Pepa Falomir, Santiago García and Tahiche Lacomba for their help at various stages of our field and laboratory work. We also thank two anonymous referees for valuable comments. We are grateful to the Consellería de Medio Ambiente de la Comunidad Valenciana for the facilities given. This work was funded by a European Commission project (SWALE, Environment Project ENV4-CT97-0420).

\section{References}

Atkinson D. (1994) Temperature and organism size. A biological law for ectotherms. Advances in Ecological Research, 25, 1-58.

Bachmann R.W., Jones B.L., Fox D.D., Hoyer M., Bull L.A. \& Canfield D.E. Jr (1996) Relations between trophic state indicators and fish in Florida (U.S.A.) lakes. Canadian Journal of Fisheries and Aquatic Sciences, 53, 842-855.

Bachmann R.W., Hoyer M.V. \& Canfield D.E. Jr (1999) The restoration of Lake Apopka in relation to alternative stable states. Hydrobiologia, 394, 219-232.

Bailey-Watts A. \& Kirika A. (1999) Poor water quality in Loch Leven (Scotland) in 1995 in spite of reduced phosphorus loadings since 1985: the influences of catchment management and inter-annual weather variation. Hydrobiologia, 403, 135-151.

Beklioglu M., Ince O. \& Tuzun I. (2003) Restoration of the eutrophic lake Eymir, Turkey, by biomanipulation after a major external nutrient control I. Hydrobiologia, 489, 93-105.

Benndorf J. (1990) Conditions for effective biomanipulation; conclusions derived from whole-lake experiments in Europe. Hydrobiologia, 200/201, 187-203.

Benndorf J., Kranich J., Mehner T. \& Wagner A. (2001) Temperature impact on the midsummer decline of Daphnia galeata: an analysis of long-term data from the biomanipulated Bautzen Reservoir (Germany). Freshwater Biology, 46, 199-211.

Bertolo A., Lacroix G., Lescher-Moutoué F. \& CardinalLegrand C. (2000) Plankton dynamics in planktivoreand piscivore- dominated mesocosms. Archiv für Hydrobiologie, 147, 327-349.

Blanco S., Romo S. \& Villena M.J. (2004) Experimental study on the diet of mosquitofish (Gambusia holbrooki) under different ecological conditions in a shallow lake. International Review of Hydrobiology, 89, 250-262.

Blanco S., Romo S., Villena M.J. \& Martínez S. (2003) Fish communities and food web interactions in six shallow Mediterranean lakes. Hydrobiologia, 506/509, 473-480.

Blindow I. (1992) Decline of charophytes during eutrophication: comparison with angiosperms. Freshwater Biology, 28, 1-14.

Camargo A. \& Esteves F. (1995) Biomass and productivity of aquatic macrophytes in Brazilian lacustrine ecosystems. In: Limnology in Brazil (Eds J.G. Tundisi, C.E.M. Bicudo \& T.M. Tundisi), pp. 137-149. Brazilian Academy of Sciences, Rio de Janeiro.

Drenner R.W. \& Hambright K.D. (1999) Biomanipulation of fish assemblages as a lake restoration technique. Archiv für Hydrobiologie, 146, 129-165. 
Drenner R.W. \& MacComas S.R. (1980) The role of zooplankter escape ability in the selective feeding and impact of planktivorous fish. In: Evolution and Ecology of Zooplankton Communities (Ed. W.C. Kerfoot), pp. 587-593. The University Press of New England, Hannover, U.S.A.

Fernando C.H. (1994) Zooplankton, fish and fisheries in tropical freshwaters. Hydrobiologia, 272, 105-123.

Forsberg C. (1964) Phosphorus, a maximum factor in the growth of Characeae. Nature, 201, 517-518.

Galanti G., Guilizzoni P. \& Libera V. (1990) Biomanipulation of Lago di Candia (Northern Italy): a three year experience of aquatic macrophyte management. $\mathrm{Hy}$ drobiologia, 200/201, 409-417.

Gliwicz Z.M. (2002) On the different nature of top-down and bottom-up effects in pelagic food webs. Freshwater Biology, 47, 2296-2312.

Hurlbert S.M., Zedler J. \& Fairbanks D. (1972) Ecosystem alteration by mosquitofish (Gambusia affinis) predation. Science, 175, 639-641.

Jeppesen E., Jensen J.P., Kristensen P., Søndergaard M., Mortensen M., Sortkjar O. \& Olrik K (1990) Fish manipulation as a lake restoration tool in shallow, eutrophic, temperate lakes. II. Threshold levels, longterm stability and conclusions. Hydrobiologia, 200/201, 219-227.

Jeppesen E., Søndergaard Ma., Søndergaard Mo. \& Chistoffersen K. (1997) The Structuring Role of Submerged Macrophytes in Lakes. Ecological Studies, Vol. 131. Springer-Verlag, New York.

Jeppesen E., Søndergaard M, Jensen J.P. \& Lauridsen T.L. (2003) Recovery from eutrophication. In: Freshwater Management. Global versus Local Perspectives (Eds M. Kumagai \& W.F. Vincent), pp. 1-16. Springer-Verlag, New York.

John D. (1986) The inland waters of tropical West Africa. Archiv für Hydrobiologie, Advances in Limnology, 23, 1-244.

Komárek J. (1985) Do all cyanophytes have a cosmopolitan distribution? Survey of the freshwater cyanophyte flora of Cuba. Archiv für Hydrobiologie, Advances in Limnology, 38/39, 359-386.

Lauridsen T.L., Pedersen L.J., Jeppesen E. \& Søndergaard M. (1996) The importance of macrophyte bed size for cladoceran composition and horizontal migration in a shallow lake. Journal of Plankton Research, 18, 22832294.

Lazzaro X. (1997) Do the trophic cascade hypothesis and classical biomanipulation approaches apply to tropical lakes and reservoirs? Verhandlungen der Internationalen Vereinigung für Theoretische und Angewandte Limnologie, 26, 719-730.

Lazzaro X., Bouvy M., Ribeiro-Filho R., Oliviera V., Sales L., Vasconcelos A. \& Mata M. (2003) Do fish regulate phytoplankton in shallow eutrophic Northeast Brazilian reservoirs. Freshwater Biology, 48, 649668.

Mazzeo N., Rodríguez-Gallego L., Kruk C., Meerhoff M., Gorga J., Lacerot G., Quintans F., Loureiro M., Larrea D. \& García-Rodríguez F. (2003) Effects of Egeria densa Planch. beds on a shallow lake without piscivorous fish. Hydrobiologia, 506-509, 591-602.

Meerhoff M., Mazzeo N., Moss B. \& Rodríguez-Gallego L. (2003) The structuring role of free-floating versus submerged plants in a shallow subtropical lake. Aquatic Ecology, 37, 377-391.

Mehner T., Benndorf J., Kasprzak P. \& Koschel R. (2002) Biomanipulation of lake ecosystems: successful applications and expanding complexity in the underlying science. Freshwater Biology, 47, 2453-2465.

Moore M.V., Folt C.L. \& Stemberger R.S. (1996) Consequences of elevated temperatures for zooplankton assemblages in temperate lakes. Archiv für Hydrobiologie, 135, 289-319.

Nicklisch A. \& Kohl J.G. (1989) The influence of light on the primary production of two planktic blue-green algae. Archiv für Hydrobiologie, 33, 451-455.

Noges T. \& Noges P. (1999) The effect of extreme water level decrease on hydrochemistry and phytoplankton in a shallow eutrophic lake. Hydrobiologia, 408/409, 277-283.

Perrow M.R., Meijer M.L., Dawidowicz P. \& Coops H. (1997) Biomanipulation in shallow lakes: state of the art. Hydrobiologia, 342/343, 355-365.

Pollingher U. \& Berman T. (1991) Phytoplankton composition and activity in lakes of the warm belt. Verhandlungen der Internationalen Vereinigung für Theoretische und Angewandte Limnologie, 24, 12301234.

Reynolds C.S. (1984) The Ecology of Freshwater Phytoplankton. Cambridge University Press, Cambridge, U.K.

Romo S. (1994) Growth parameters of Pseudanabaena galeata Böcher in culture under different light and temperature conditions. Archiv für Hydrobiologie, Advances in Limnology, 75, 239-248.

Romo S. \& Miracle R. (1993a) Long-term periodicity of Planktothrix agardhii, Pseudanabaena galeata and Geitlerinema sp. in a shallow hypertrophic lagoon, the Albufera of Valencia (Spain). Archiv für Hydrobiologie, 126, 469-486.

Romo S. \& Miracle R. (1993b) Population dynamics and ecology of subdominant phytoplankton species in a shallow hypertrophic lake (Albufera of Valencia, Spain). Hydrobiologia, 273, 37-56.

Sas H. (1989) Lake Restoration by Reduction of Nutrient Loading: Expectations, Experiences, Extrapolations. Academia Verlag Richarz, St Augustin, Germany. 
Scheffer M. (1998) Ecology of Shallow Lakes. Chapman and Hall, New York.

Scheffer M., Hosper S.H., Meijer M.L., Moss B. \& Jeppesen E. (1993) Alternative equilibria in shallow lakes. Trends in Ecology and Evolution, 8, 275-279.

Scheffer M., Rinaldi S., Gragnani A., Mur L. \& van Nes E.H. (1997) On the dominance of filamentous cyanobacteria in shallow, turbid lakes. Ecology, 78, 272-282.

Stephen D., Balayla D., Bécares E. et al. (2004a) Continental-scale patterns of nutrient and fish effects on shallow lakes: introduction to a pan-European mesocosm experiment. Freshwater Biology, 49, 1517-1524.

Stephen D., Balayla D.M., Collings S.E. \& Moss B. (2004b) Two mesocosm experiments investigating the control of summer phytoplankton growth in a small shallow lake. Freshwater Biology, 49, 1551-1564.

Talling J.F \& Lemoalle J. (1998) Ecological Dynamics of Tropical Inland Waters. Cambridge University Press, Cambridge.
Vakkilainen K., Kairesalo T., Hietala J. et al. (2004) Response of zooplankton to nutrient enrichment and fish in shallow lakes: a pan-European mesocosm experiment. Freshwater Biology, 49, 1619-1632.

Van den Berg M., Scheffer M. \& Coops H. (1998) The role of characean algae in the management of eutrophic shallow lakes. Journal of Phycology, 34, 750-756.

Van den Berg M., Scheffer M., Van Nes E. \& Coops H. (1999) Dynamics and stability of Chara sp. and Potamogeton pectinatus in a shallow lake changing in eutrophication level. Hydrobiologia, 408/409, 335-342.

Vanni M.J. (1987) Effects of nutrients and zooplankton size on the structure of a phytoplankton community. Ecology, 68, 624-635.

Weisner S., Strand J. \& Sandsten H. (1997) Mechanisms regulating abundance of submerged vegetation in shallow eutrophic lakes. Oecologia, 109, 592-599.

(Manuscript accepted 3 September 2004) 